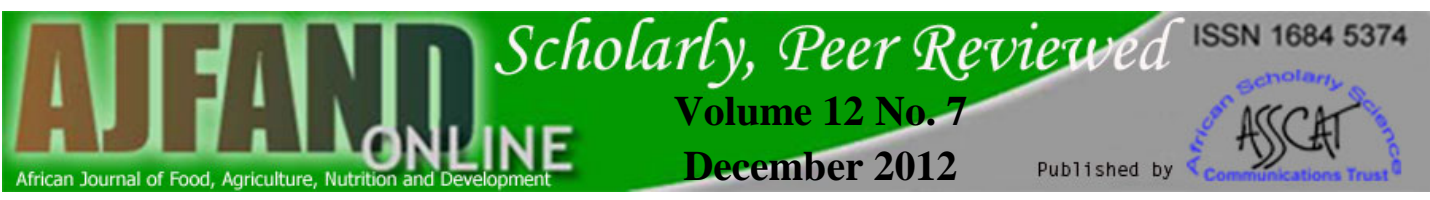

\title{
EVALUATION OF COCONUT-CITRUS INTERCROPPING SYSTEMS IN THE CONTEXT OF LETHAL YELLOWING DISEASE OF COCONUT IN GHANA
}

\section{Andoh-Mensah $\mathrm{E}^{*^{1}}$ and GK Ofosu-Budu ${ }^{2}$}

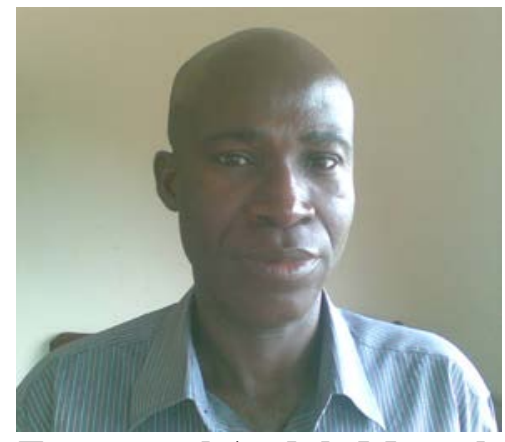

Emmanuel Andoh-Mensah

*Corresponding author’s E-mail: andomens@yahoo.com

${ }^{1}$ M.Phil. Senior Research Scientist, CSIR- Oil Palm Research Institute, Coconut Programme, P. O. Box 245, Sekondi, Ghana.

${ }^{2} \mathrm{PhD}$, Senior Lecturer, Forest and Horticultural Crops Research Centre, OkumaningKade, College of Agriculture and Consumer Sciences, University of Ghana, Legon, Ghana 


\section{ABSTRACT}

Global coconut production is under the devastating threat of lethal yellowing diseases endemic in East and West Africa. The most practical solution to the disease problem lies in the development of resistant or tolerant coconut planting materials. Malayan Yellow Dwarf (MYD) crossed (x) Vanuatu Tall (VTT) coconut hybrid was identified in a resistance screening work to have moderate tolerance to the disease. Consequently, the hybrid was recommended for replanting of coconut fields devastated by lethal yellowing in Ghana. To stimulate a greater replanting effort however, there was the need to develop a more efficient coconut intercropping systems involving other economic tree crops that are capable of providing insurance against total crop failure and loss of income since the MYD x VTT coconut hybrid was only moderately tolerant to lethal yellowing. Four cropping systems involving the tolerant MYD x VTT coconut hybrid and Late Valencia sweet orange were evaluated in a randomized complete block design with three replicates. The cropping systems were: 1 . Sole coconut (Coconut planted at $8.5 \mathrm{~m}$ triangular spacing at $160 \mathrm{palms} \mathrm{ha}^{-1}$ ) 2. Sole citrus (Citrus planted at $6 \mathrm{~m}$ square spacing at 277 trees ha- ${ }^{-1}$ ) 3 . Coconut-citrus intercrop I (Coconut planted at $9.5 \mathrm{~m}$ triangular spacing at 128 palms ha ${ }^{-1}$ and intercropped with citrus at 100 trees $\mathrm{ha}^{-1}$ ) 4 . Coconut-citrus intercrop II (Coconut planted at $10.5 \mathrm{~m}$ triangular spacing at 105 palms ha $^{-1}$ and intercropped with citrus at 80 trees $\mathrm{ha}^{-1}$ ). Citrus was planted at the convergence point of any two diagonal lines linked with four adjacent coconut palms. The MYD x VTT coconut hybrid planted at $9.5 \mathrm{~m}$ triangular provided optimal spacing for citrus intercropping. The intercropping system did not hinder the optimal growth and yield of coconut or citrus. It enabled a more efficient use of land and generated higher productivity by fitting more trees (coconut/ citrus) to a unit area of land as compared with sole cropping. The costbenefit ratio of the intercropping came next to sole coconut planting. Nevertheless, intercropping enjoyed 26\% of fruit income as insurance against lethal yellowing disease while sole coconut planting had no insurance cover.

Key words: Coconut, Lethal yellowing, Citrus, Intercropping 


\section{INTRODUCTION}

The lethal yellowing disease (LYD) of coconut constitutes the most important single threat to coconut production in the world including a number of African countries [1, 2, 3]. The disease is caused by phytoplasma and is endemic in East and West Africa. In East Africa, LYD is known collectively as Lethal Disease (LD) as opposed to West Africa where the disease is named differently as Cape St Paul Wilt in Ghana, Awka wilt in Nigeria, Kribi in Cameroon and Kaincope in Togo.

In Ghana, the disease has caused the Volta Region, where it was first observed in 1932 to lose its status as one of the three major coconut growing regions in the country. For the remaining two major coconut growing regions (Western and Central), the disease had devastated about 5,500 ha of coconut farms leading to economic hardships for thousands of farmers whose livelihood depends on the crop [4]. The spread of the disease still continues. Typical symptoms are pre-mature dropping of nuts, blackening or necrosis of inflorescence, yellowing or browning of leaves and topping over of crown leaving characteristic 'telegraph poles' in its trail.

The most practical solution to the disease problem lies in the development of resistant or tolerant coconut planting materials [5, 6]. The Malayan Yellow Dwarf (MYD) crossed (x) Vanuatu Tall (VTT) coconut hybrid was identified in an earlier resistance screening work to have moderate tolerance to the disease and good agronomic characteristics [1]. Consequently, the hybrid was recommended to the Coconut Sector Development Project of Ghana for replanting of coconut fields devastated by LYD [7].

To stimulate a greater replanting effort however, there was the need to develop a more efficient coconut intercropping systems involving other economic tree crops that are capable of providing insurance against total crop failure and loss of income [8] since the MYD x VTT coconut hybrid was only moderately tolerant to LYD. Sweet orange (Citrus sinensis L. Osbeck) was identified as one of the economic tree crops grown commercially and sometimes side by side with coconut in the coconut belt of Ghana. Other suitable tree crops include cocoa and rubber.

This work sought to develop a more efficient intercropping systems involving coconut and citrus with the following specific objectives: (1) to identify optimum spacing of coconut for intercropping with citrus (2) to assess the effect of intercropping on the performance of coconut and citrus and (3) to do agronomic and economic analysis of the coconut-citrus intercropping systems.

\section{MATERIALS \& METHODS}

\section{Study location}

The study was carried out from 2002 to 2008 in the coconut belt of southern Ghana at three locations namely; Agona - Nkwanta; Ayensudo - Enyenase and Aburansa. Annual rainfall of the locations varies from $1200-1500 \mathrm{~mm}$ and is distributed bimodally with the major peak in June-July and a minor peak in September - 
October. Soils at the locations (Table 1) were suitable for coconut and citrus production except that fertilizer application was necessary.

\section{Experimental design}

Four cropping systems involving MYD x VTT coconut hybrid and Late Valencia sweet orange on rough lemon root stock were randomly assigned to four distinct plots of size 0.65 acres at each of the three locations to obtain a randomized complete block design with three replicates. The cropping systems were: 1 . Sole coconut (Coconut planted at $8.5 \mathrm{~m}$ triangular spacing at $160 \mathrm{palms} \mathrm{ha}^{-1}$ ) 2. Sole citrus (Citrus planted at $6 \mathrm{~m}$ square spacing at 277 trees ha ${ }^{-1}$ ) 3 . Coconut-citrus intercrop I (Coconut planted at $9.5 \mathrm{~m}$ triangular spacing at 128 palms ha $^{-1}$ and intercropped with citrus at 100 trees ha$\left.{ }^{1}\right)$ 4. Coconut-citrus intercrop II (Coconut planted at $10.5 \mathrm{~m}$ triangular spacing at 105 palms ha ${ }^{-1}$ and intercropped with citrus at 80 trees $^{-1}{ }^{-1}$ ). Citrus was planted at the convergence point of any two diagonal lines linked with four adjacent coconut palms.

\section{Food crop intercropping}

Intercropping tree crops with staple food crops before canopy closure is a very important practice by farmers. Consequently, available interspaces between the coconut and citrus were uniformly intercropped with cassava, followed by maize and vegetable within the first three years of the trial. Food crops were planted $1 \mathrm{~m}$ away from either coconut or citrus in year one and $1.5 \mathrm{~m}$ away in years two and three to minimize competition between the test trees and food crops.

\section{Fertilizer application}

Urea was applied as source of $\mathrm{N}$; Muriate of potash as source of $\mathrm{K}_{2} \mathrm{O}$; Magnesium Sulphate as source of $\mathrm{MgO}$ and triple superphosphate as source of $\mathrm{P}_{2} \mathrm{O}_{5}$. Coconut was given $276 \mathrm{~g} \mathrm{~N}$; 204g $\mathrm{P}_{2} \mathrm{O}_{5} ; 1,440 \mathrm{~g} \mathrm{~K}_{2} \mathrm{O}$ and $240 \mathrm{~g} \mathrm{MgO}$ per palm in three annual split applications. For citrus fertilization, $184 \mathrm{~g} \mathrm{~N} ; 132 \mathrm{~g} \mathrm{P}_{2} \mathrm{O}_{5}$ and $720 \mathrm{~g} \mathrm{~K}_{2} \mathrm{O}$ were applied per tree in three annual splits.

\section{Data collection and derivation}

Growth of coconut was assessed at six-monthly intervals by measurement of collar girth at soil level and count of newly emerged leaves. Nuts in bunches of leaf ranks 14, 19 and 24 were counted and their mean multiplied by 12 to estimate nut load palm- $^{1} \mathrm{yr}^{1}{ }^{1}$ [9]. Growth of citrus was determined at six-monthly intervals by measurement of plant height, stem girth and canopy width. Height was measured from bud-union level to shoot apex. Girth was taken at $5 \mathrm{~cm}$ above bud-union level. Canopy width was measured in the North-South and East-West directions and their mean calculated. Following the procedure of [10], canopy volume was derived as:

$\frac{4}{3} \pi[\text { plant height] [canopy radius }]^{2}$ 
Fruit yield per hectare was estimated from fruit count per tree and mean fruit weight. Land Equivalent Ratio (LER) was estimated using the procedure of [11]:

$L E R=\left[\frac{\text { Pcoconut }}{\text { Mcoconut }}+\frac{\text { Pcitrus }}{\text { Mcitrus }}\right]$

Where:

Pcoconut $=$ Intercropped yield of coconut

Pcitrus = Intercropped yield of citrus

Mcoconut $=$ Monocropped yield of coconut

Mcitrus $=$ Monocropped yield of citrus

\section{Statistical analysis}

GenStat Discovery (Edition 3) software was used for statistical analysis. Data were subjected to Two-Way Analysis of Variance (in Randomized Blocks) to be able to factor time into the analysis of repeated measures. Means were separated by Least Significant Difference (LSD).

\section{Economic analysis}

The economic analysis of the cropping systems was assessed by evaluating the net income, cost-benefit ratio and insurance against lethal yellowing disease (LYD). The net income was obtained by deducting input cost from gross income. The costbenefit ratio was determined by dividing gross income by input cost. Insurance against LYD was estimated by expressing citrus income as a percentage of the total fruit (coconut + citrus) income.

\section{RESULTS}

\section{Growth and yield performance of citrus}

Growth of late Valencia sweet orange as measured by rate of increase of plant height, stem girth, canopy radius and canopy volume went through exponential, stabilization and decline phases. Increase in growth parameters was highly significant $(\mathrm{P}<0.01)$ between sampling times but between the cropping systems there were no significant ( $P>0.05$ ) differences except for plant height (Table 2). Height of late Valencia came up significantly $(\mathrm{P}<0.05)$ taller in coconut-citrus intercrop II $(452.4 \mathrm{~cm})$ compared with coconut-citrus intercrop I $(420.5 \mathrm{~cm})$ at 54 months after planting.

Cropping system did not have significant $(\mathrm{P}>0.05)$ effect on fruit weight per tree but it had significant $(\mathrm{P}<0.05)$ influence on fruit yield per hectare (Table 3$)$. Fruit yield per hectare averaged over 2 years was significantly $(\mathrm{P}<0.05)$ greater in the sole citrus compared to the intercropping systems. Fruit yield of late Valencia in coconut-citrus intercrop I did not differ significantly $(\mathrm{P}>0.05)$ from that of coconut-citrus intercrop II (Table 4). 


\section{Growth and yield performance of coconut}

Like late Valencia sweet orange, growth of MYD x VTT coconut hybrid as measured by rate of increase of collar girth underwent exponential, stabilization and decline stages. Cumulative leaf number increased progressively over the study period. Increase in collar girth and cumulative leaf number was highly significant $(\mathrm{P}<0.01)$ between sampling times. Cropping system affected collar girth of coconut significantly $(\mathrm{P}<0.05)$ but not cumulative leaf number (Table 5$)$. Collar girth of coconut grew significantly $(\mathrm{P}<0.05)$ larger in coconut-citrus intercrop II $(93.7 \mathrm{~cm})$ relative to coconut-citrus intercrop I $(75.4 \mathrm{~cm})$ after 30 months in the field.

Cropping system did not have significant $(\mathrm{P}>0.05)$ effect on nut load per tree but it had significant $(\mathrm{P}<0.01)$ influence on nut yield per hectare (Table 6). Nut yield per hectare averaged over two years was significantly $(\mathrm{P}<0.05)$ greater in the sole coconut compared to the intercropping systems. Nut yield of coconut in coconut-citrus intercrop I did not differ significantly $(\mathrm{P}>0.05)$ from that of coconut-citrus intercrop II (Table 7).

\section{Agronomic and economic analysis}

Coconut-citrus intercrop I had the greatest land equivalent ratio (LER) with the least LER observed under coconut-citrus intercrop II. A 7\% less land was required under coconut-citrus intercrop I to produce the same quantity of coconut and citrus yields as under the sole cropping (Table 8). Net income per hectare was highest for sole coconut which generated $71.2 \%, 62.4 \%$ and $16.7 \%$ more income than sole citrus, coconut-citrus intercrop II and intercrop I, respectively. Similarly, cost-benefit ratio was highest for sole coconut, followed closely by coconut-citrus intercrop I, coconutcitrus intercrop II and sole citrus. While coconut-citrus intercrops I and II respectively enjoy $26.1 \%$ and $21.9 \%$ of their fruit incomes as insurance against the lethal yellowing disease, sole coconut had no insurance cover (Table 9).

\section{DISCUSSION}

\section{Growth and yield performance of coconut and citrus}

Growth of citrus and coconut in the cropping systems followed a normal biological growth pattern [12]. The exponential phase was in conformity with the juvenile stage when vegetative growth occurred at increased rates to accumulate maximum dry matter and to attain optimum leaf area index. The stabilization phase probably occurred at the time of optimum leaf area index and maximum dry matter accumulation. The decline phase was probably indicative of floral initiation when the greater sink strength of floral structures accumulated more assimilates relative to vegetative structures. The progressive increase in cumulative leaf number of coconut was in conformity with the known emergence of 12 leaves per year in coconut [9] barring any growth limitation.

Relative to the sole crops the intercropping systems (coconut-citrus intercrops I and II) did not hinder the optimum growth of either MYD x VTT coconut hybrid or late Valencia sweet orange. This might indicate coconut-citrus compatibility and buttress 
the practice of intercropping as the major cropping system for coconut cultivation worldwide [13, 14, 15]. The wider spatial arrangement of coconut-citrus intercrop II tends to stimulate taller height in citrus and larger collar girth in coconut compared to coconut-citrus intercrop I. This might be attributed to lower plant population in coconut-citrus intercrop II which probably led to better availability of growth resources such as light, water and nutrients $[16,17]$.

Like the growth of citrus and coconut, the intercropping systems did not adversely affect fruit weight of citrus or nut load of coconut per tree. On per hectare basis therefore differences in citrus or coconut yield between the cropping systems could be attributed mainly to variation in coconut or citrus density per hectare.

The long term effects of the intercropping systems on yield of coconut and citrus need to be established since at this stage (6 years after planting) yield was only preliminary. The possibility of shading effect in the future particularly in coconut-citrus intercrop I, the promising intercropping system, cannot be ruled out. Shading effect, if permitted, could cause several problems including delayed ripening, reduced yields and poor fruit quality of citrus [18]. Consequently, this study needs to be continued to monitor the effect of shading (if any) on fruit yield and quality.

\section{Agronomic and economic analysis}

Coconut-citrus intercrop I had the greatest land equivalent ratio; an indication of a more efficient land use and higher productivity under intercropping [19]. The 7\% less land required under coconut-citrus intercrop I to produce the same quantity of coconut and citrus yields as under the sole cropping implied that more trees (coconut/ citrus) could be fitted to a unit area of land under intercropping. Apart from the high efficiency and productivity of coconut-citrus intercrop I, the $26.1 \%$ of fruit income enjoyed as insurance against the lethal yellowing disease could be a source of motivation for farmers who are skeptical to plant the improved coconut hybrid (MYD $\mathrm{x}$ VTT). The superior net income and cost-benefit ratio generated on per hectare basis by sole coconut followed by coconut-citrus intercrop I, coconut-citrus intercrop II and sole citrus was due to the higher farm gate price of coconut (four-fold higher than citrus). Any future improvement in the market trends of citrus relative to coconut could make the fruit income of the intercropping systems much better than sole coconut.

\section{CONCLUSION}

The six-year preliminary study showed that MYD x VTT coconut hybrid planted at $9.5 \mathrm{~m}$ triangular offered optimal spacing for citrus intercropping at the convergence point of two diagonal lines linked with four adjacent coconut palms. The intercropping system did not hinder the optimal growth and yield of coconut or citrus. It enabled a more efficient use of land and generated higher productivity by fitting more trees (coconut/ citrus) to a unit area of land as compared with sole cropping. The cost-benefit ratio of the intercropping came next to sole coconut planting. Nevertheless, intercropping enjoyed 26\% of fruit income as insurance against lethal yellowing disease while sole coconut planting had no insurance cover.

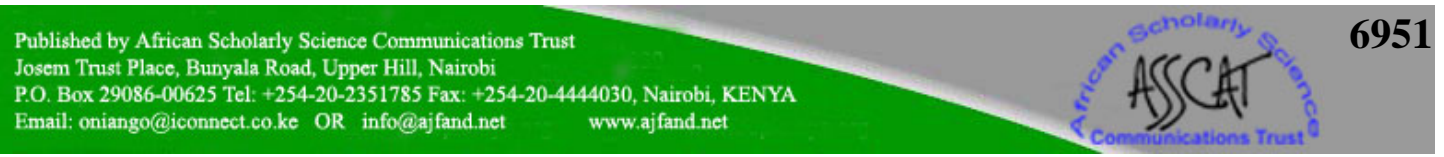




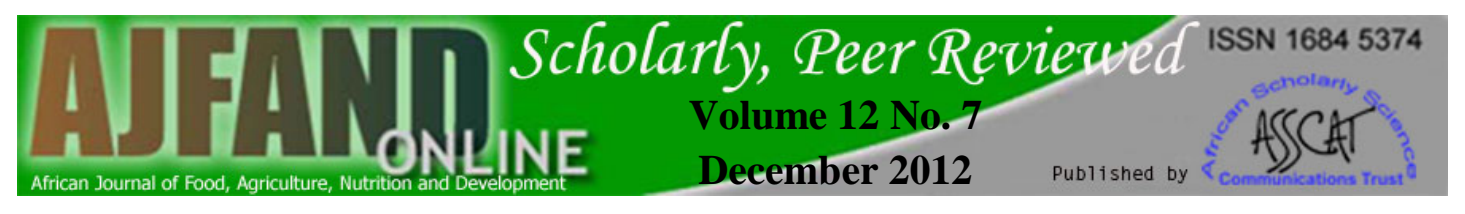

\section{ACKNOWLEDGEMENT}

The authors hereby acknowledge the financial assistance given under the Agricultural Services Sub-sector Investment Project (AgSSIP) funded by the World Bank. They also wish to express their gratitude to the following staff of the Oil Palm Research Institute Coconut Programme: Messrs Richard Nkrumah, Kenneth Atta-Peters, Joseph Martin-Bannerman, Elizabeth Adjei and John Ediyie for their immense technical support. 
Table 1: Some Chemical Properties of Soils at Experimental Locations in 2002

\begin{tabular}{|c|c|c|c|c|c|c|c|c|}
\hline \multirow[t]{2}{*}{ Location } & \multirow{2}{*}{$\begin{array}{r}\text { (cm) } \\
\text { Depth }\end{array}$} & \multirow{2}{*}{$\begin{array}{c}\left(\mathrm{H}_{2} \mathrm{O}\right) \\
\mathbf{P H} \\
\end{array}$} & \multicolumn{2}{|c|}{-------\%------- } & \multirow{2}{*}{$\begin{array}{c}\text { mgkg }^{-1} \\
\text { Avail. } \mathbf{P}\end{array}$} & \multicolumn{3}{|c|}{---------Cmolkg ${ }^{-1}-----$} \\
\hline & & & $\mathbf{N}$ & O.M & & $\mathbf{K}$ & Ca & Mg \\
\hline \multirow[t]{2}{*}{ Agona } & $0-20$ & 5.28 & 0.09 & 2.85 & 3.56 & 0.03 & 1.94 & 1.50 \\
\hline & $20-40$ & 5.02 & 0.07 & 2.14 & 1.74 & 0.02 & 1.44 & 1.20 \\
\hline \multirow[t]{2}{*}{ Aburansa } & $0-20$ & 6.05 & 0.16 & 3.86 & 3.53 & 0.10 & 5.25 & 2.95 \\
\hline & $20-40$ & 5.78 & 0.11 & 2.92 & 1.28 & 0.07 & 3.90 & 2.35 \\
\hline \multirow[t]{2}{*}{ Enyenase } & $0-20$ & 6.24 & 0.18 & 4.51 & 2.68 & 0.06 & 5.86 & 3.60 \\
\hline & $20-40$ & 6.06 & 0.11 & 3.12 & 1.29 & 0.03 & 4.06 & 2.83 \\
\hline
\end{tabular}




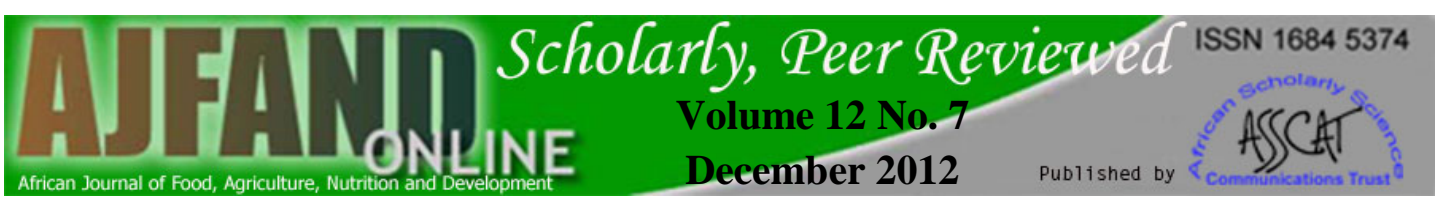

Table 2: Two-Way Analysis of Variance of Growth Performance of Late Valencia Sweet Orange in Coconut-Citrus Intercropping Systems

\begin{tabular}{cccccc}
\hline Source of variation & Df & $\begin{array}{c}\text { Sum of } \\
\text { Square }\end{array}$ & $\begin{array}{c}\text { Mean } \\
\text { Square }\end{array}$ & $\begin{array}{c}\text { Var } \\
\text { Ratio }\end{array}$ & $\begin{array}{c}\text { F } \\
\text { Prob }\end{array}$ \\
\hline
\end{tabular}

\section{Plant height}

Cropping system

Time

Cropping system. Time

$\begin{array}{ccccc}2 & 2290.8 & 1145.4 & 3.33 & 0.046^{*} \\ 6 & 874078.8 & 145679.8 & 424.08 & <0.001^{* *} \\ 12 & 1275.5 & 106.3 & 0.31 & 0.984^{\text {ns }}\end{array}$

\section{Stem girth}

Cropping system

$2 \quad 25.221$

12.610

2.23

$0.121^{\mathrm{ns}}$

Time

$6 \quad 9745.193$

1624.199

$286.66<0.001^{* *}$

Cropping system. Time

12

35.192

2.933

0.52

$0.891^{\text {ns }}$

\section{Canopy radius}

Cropping system

Time

2

$$
319.3
$$

159.6

1.45

$0.256^{\mathrm{ns}}$

Cropping system. Time

3

69639.7

23213.2

210.74

$<0.001^{* *}$

6

195.6

32.6

0.30

$0.932^{\text {ns }}$

\section{Canopy volume}

Cropping system

Time

279.02

39.51

0.69

$0.510^{\mathrm{ns}}$

Cropping system. Time

$3 \quad 12954.00$

4318.00

75.79

$<0.001^{* *}$

6

72.54

12.09

0.21

$0.969^{\mathrm{ns}}$ 


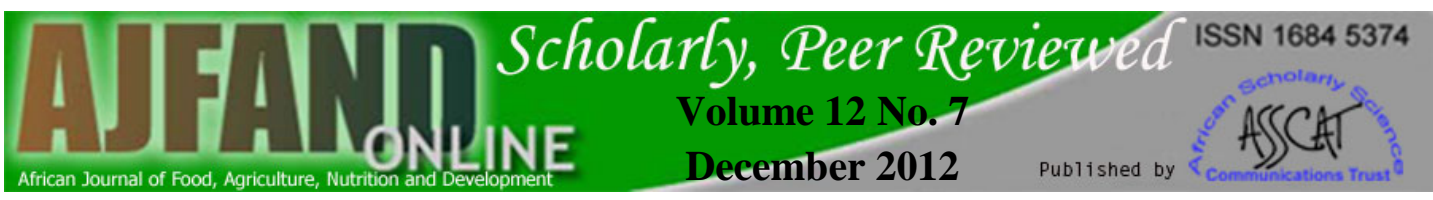

Table 3: Two-Way Analysis of Variance of Fruit Yield Performance of Late Valencia Sweet Orange in Coconut-Citrus Intercropping Systems

\begin{tabular}{lccccc}
\hline Source of variation & Df & $\begin{array}{c}\text { Sum of } \\
\text { Square }\end{array}$ & $\begin{array}{c}\text { Mean } \\
\text { Square }\end{array}$ & $\begin{array}{c}\text { Var } \\
\text { Ratio }\end{array}$ & $\begin{array}{c}\text { F } \\
\text { Prob }\end{array}$ \\
\hline
\end{tabular}

\section{Fruit weight/ tree}

Cropping system

$$
2
$$

328.3

164.1

1.28

$0.320^{\mathrm{ns}}$

Time

1

911.6

911.6

7.10

$0.024^{*}$

Cropping system. Time

2

372.1

186.1

1.45

$0.280^{\mathrm{ns}}$

\section{Fruit weight/ ha}

Cropping system

2

159.99

79.99

4.50

$0.040^{*}$

Time

\section{1}

38.43

38.43

2.16

$0.172^{\mathrm{ns}}$

Cropping system. Time

2

44.53

22.26

1.25

$0.327^{\mathrm{ns}}$ 


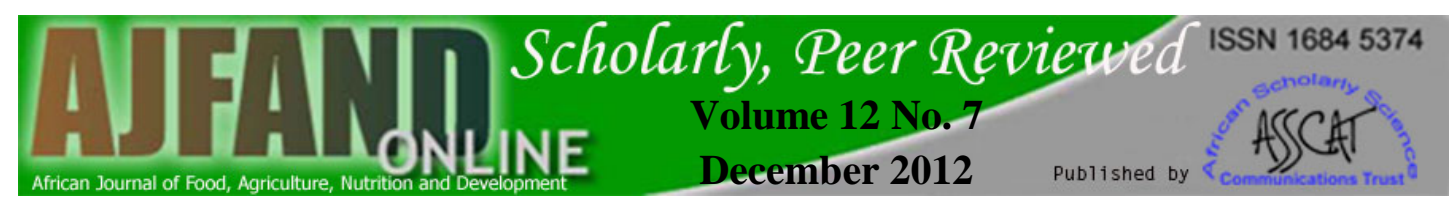

Table 4: Fruit yield of late Valencia sweet orange in coconut-citrus intercropping systems

\begin{tabular}{|c|c|c|c|c|c|c|}
\hline \multirow[t]{3}{*}{ Cropping System } & \multicolumn{6}{|c|}{ Fruit Yield } \\
\hline & \multicolumn{2}{|c|}{----Yr. 5---- } & \multicolumn{2}{|c|}{----Yr. 6---- } & \multicolumn{2}{|c|}{-----Mean---- } \\
\hline & $\begin{array}{c}\text { Fruit wt } \\
\text { per tree } \\
\text { (kg) }\end{array}$ & $\begin{array}{l}\text { Fruit wt } \\
\text { per ha } \\
\text { (t) }\end{array}$ & $\begin{array}{c}\text { Fruit wt } \\
\text { per tree } \\
\text { (kg) }\end{array}$ & $\begin{array}{l}\text { Fruit wt } \\
\text { per ha } \\
\text { (t) }\end{array}$ & $\begin{array}{l}\text { Fruit wt } \\
\text { per tree } \\
\text { (kg) }\end{array}$ & $\begin{array}{c}\text { Fruit wt } \\
\text { per ha } \\
\text { (t) }\end{array}$ \\
\hline Sole Citrus & 18.9 & 5.27 & 45.6 & 12.63 & 32.3 & 8.95 \\
\hline Coconut-Citrus Intercrop I & 32.6 & 3.27 & 37.9 & 3.80 & 35.3 & 3.54 \\
\hline Coconut-Citrus Intercrop II & 19.7 & 1.57 & 30.4 & 2.43 & 25.1 & 2.00 \\
\hline$L S D D_{0.05}$ & 20.6 & 3.09 & 20.8 & 7.67 & 20.7 & 5.38 \\
\hline
\end{tabular}

wt $=$ Weight 


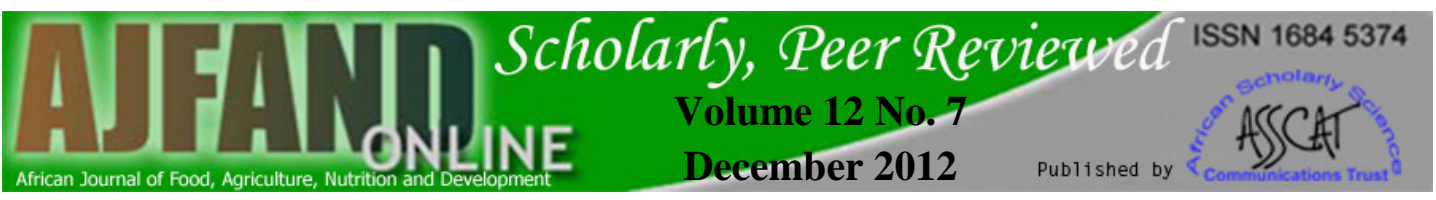

Table 5: Two-Way Analysis of Variance of Growth Performance of MYD x VTT Coconut Hybrid in Coconut-Citrus Intercropping Systems

\begin{tabular}{lccccc}
\hline Source of variation & Df & $\begin{array}{c}\text { Sum of } \\
\text { Square }\end{array}$ & $\begin{array}{c}\text { Mean } \\
\text { Square }\end{array}$ & $\begin{array}{c}\text { Var } \\
\text { Ratio }\end{array}$ & $\begin{array}{c}\text { F } \\
\text { Prob }\end{array}$ \\
\hline Collar girth & & & & & \\
Cropping system & 2 & 2162.9 & 1081.4 & 9.28 & $<0.001^{* *}$ \\
Time & 6 & 72222.9 & 12037.1 & 103.30 & $<0.001^{* *}$ \\
Cropping system. Time & 12 & 635.8 & 53.0 & 0.45 & $0.929^{\text {ns }}$
\end{tabular}

\section{Cumulative leaf number}

Cropping system

Time

Cropping system. Time
2

6

12

17.810

15.746
11214.762

1869.127

1.484

0.25 $0.274^{\text {ns }}$

$<0.001^{* *}$

$0.993^{\mathrm{ns}}$

*Significant at $\mathrm{P} \leq 0.05$ ** Significant at $\mathrm{P} \leq 0.01$ ${ }^{\text {ns }}$ Not Significant at $\mathrm{P}=0.05$

$\mathrm{Df}=$ Degrees of freedom $\quad$ Var= Variance $\quad$ Prob $=$ Probability 


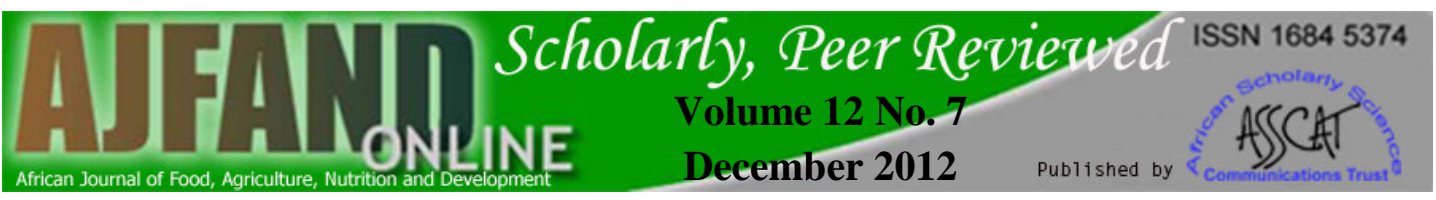

Table 6: Two-Way Analysis of Variance of Nut Yield Performance of MYD x VTT Coconut Hybrid in Coconut-Citrus Intercropping Systems

\begin{tabular}{lccccc}
\hline Source of variation & Df & Sum of & Mean & Var & F \\
& Square & Square & Ratio & Prob \\
\hline
\end{tabular}

\section{Nut load/ palm}

Cropping system

2

2665.6

1332.8

2.56

$0.138^{\mathrm{ns}}$

Time

1

662.7

662.7

1.27

$0.292^{\text {ns }}$

Cropping system. Time

2

629.0

314.5

0.60

$0.570^{\mathrm{ns}}$

Nut yield/ ha

$\begin{array}{lccccc}\text { Cropping system } & 2 & 284080159 & - & 15.18 & 0.002^{* *} \\ \text { Time } & 1 & 16956887 & - & 1.81 & 0.215^{\mathrm{ns}} \\ \text { Cropping system. Time } & 2 & 15556997 & - & 0.83 & 0.470^{\mathrm{ns}}\end{array}$

*Significant at $\mathrm{P} \leq 0.05$

** Significant at $\mathrm{P} \leq 0.01$

${ }^{\text {ns }}$ Not Significant at $\mathrm{P}=0.05$

Df= Degrees of freedom $\quad$ Var= Variance $\quad$ Prob= Probability 


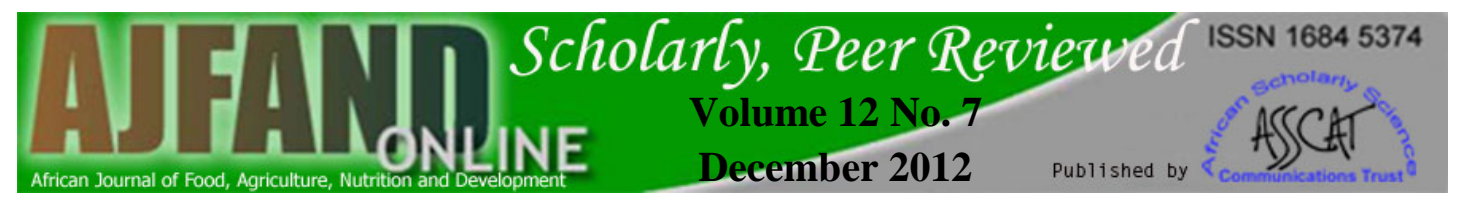

Table 7: Nut yield of MYD x VTT coconut hybrid in coconut-citrus intercropping systems

\section{Cropping System}

Cropping System

\begin{tabular}{c}
----Yr. 5---- \\
\cline { 2 - 3 } Nut yield Nut yield Nut yield Nut yiel
\end{tabular}

\begin{tabular}{lccc}
\hline Nut yield & $\begin{array}{c}\text { Nut yield } \\
\text { per palm }\end{array}$ & $\begin{array}{c}\text { Nut yield } \\
\text { per palm }\end{array}$ & $\begin{array}{c}\text { Nut yield } \\
\text { per ha }\end{array}$
\end{tabular}

Sole Coconut

(nb)

Coconut-Citrus Intercrop I

102

(nb)

16,253

95

12,112

(nb)

Coconut-Citrus Intercrop II

85

8,662

43.2

4,073

LSD $_{0.05}$

nb = number

\section{Fruit Yield}

13

(nb)

20,819

101

12,877

98

12,494

Nut yield Nut yield per palm per ha

(nb) (nb)

116

18,536




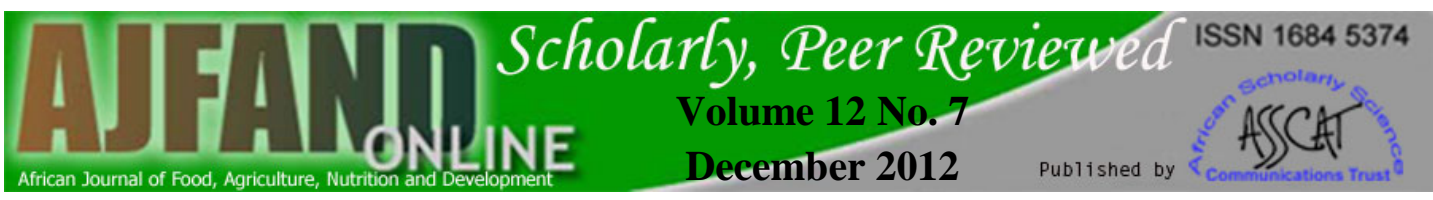

Table 8: Land equivalent ratio (LER) of coconut-citrus intercropping systems

\begin{tabular}{lccc}
\hline Cropping system & \multicolumn{2}{c}{$\begin{array}{c}\text { Fruit yield/ ha (numbers) } \\
\text { (Averaged over years 5 and 6) }\end{array}$} & LER \\
& Coconut & Citrus & \\
& 18,536 & - & 1.00 \\
Sole coconut & 12,495 & 17,620 & 1.07 \\
Coconut-citrus intercrop I & 8,909 & 10,020 & 0.70 \\
Coconut-citrus intercrop II & - & 44,735 & 1.00 \\
Sole citrus & & & \\
\hline
\end{tabular}

Table 9: Economic evaluation of coconut-citrus intercropping systems after six years

\begin{tabular}{lccccc}
\hline $\begin{array}{l}\text { Cropping } \\
\text { system }\end{array}$ & $\begin{array}{c}\text { Input cost } \\
\text { /ha } \\
\text { (US\$ ) }\end{array}$ & $\begin{array}{c}\text { Gross } \\
\text { income/ha } \\
\text { (US\$ ) }\end{array}$ & $\begin{array}{c}\text { Net } \\
\text { income/ha } \\
\text { (US\$ ) }\end{array}$ & $\begin{array}{c}\text { Cost/ } \\
\text { benefit } \\
\text { ratio }\end{array}$ & $\begin{array}{c}\text { Insurance } \\
\text { against } \\
\text { LYD }\end{array}$ \\
\hline $\begin{array}{l}\text { Sole coconut } \\
\text { (US1.68 }\end{array}$ & $2,008.04$ & $1,656.36$ & 5.7 & 0.0 \\
$\begin{array}{l}\text { Coconut-citrus } \\
\text { intercrop I }\end{array}$ & 315.77 & $1,736.67$ & $1,420.90$ & 5.5 & 26.1 \\
$\begin{array}{l}\text { Coconut-citrus } \\
\text { intercrop II }\end{array}$ & 319.51 & $1,355.12$ & $1,035.61$ & 4.2 & \\
$\begin{array}{l}\text { Sole citrus } \\
\text { 413.65 }\end{array}$ & $1,381.37$ & 967.72 & 3.3 & \\
\hline
\end{tabular}




\section{REFERENCES}

1. Dery SK, N'Cho YP, Sangare A and ED Arkhurst Cape St Paul Wilt Disease: Resistance screening and prospects for rehabilitating the coconut industry in Ghana. In: Eden Green SJ and F Ofori (Eds). Proceedings of an international workshop on lethal yellowing-like disease of coconut, Elmina, Ghana, November1995. Chatman, UK, 1997:147-152.

2. Osagie IJ and O Asemota Occurrence of Awka wilt disease of coconut in Nigeria. In: Eden Green SJ and F Ofori (Eds). Proceedings of an international workshop on lethal yellowing-like disease of coconut, Elmina, Ghana, November 1995. Chatman, UK, 1997:33-37.

3. Lourenco E The situation of the coconut palm plantation in Mozambique with a focus on the diseases affecting it. In: Proceedings of an International workshop on lethal yellowing diseases of coconut, Accra, Ghana, June 2008. Actes de l'Atelier, CSIR, FARA, CIRAD, 2008:58-66.

4. Dery SK, Philippe R, Baudouin L, Quaicoe RN, Nkansah-Poku J, OwusuNipah J, Arthur R, Dare D, Yankey $\mathbf{N}$ and $\mathbf{M}$ Dollet Genetic diversity among coconut varieties for susceptibility to CSPWD. Euphytica 2008; 164:111.

5. Mariau D, Dery SK, Sangaré A, N'Cho YP and R Philippe Le Jaunissement mortel du cocotier au Ghana et tolérance du materriel végétal. Plantations recherché developpement 1996; 3(2): 105-112.

6. Harries HC Growing coconut in Africa: resistance to lethal yellowing-like diseases. In: Eden Green SJ and F Ofori (Eds). Proceedings of an international workshop on lethal yellowing-like disease of coconut, Elmina, Ghana, November 1995. Chatman, UK, 1997: 139-146.

7. Dery SK, Philippe $\mathbf{R}$ and $\mathbf{C H}$ Calvez Report on applied research programme in agronomy and crop protection to the operator of the project (GREL). Government of the Republic of Ghana, Ministry of Food and Agriculture, Department of Crop Services, Coconut Sector Development Project. OPRI, CIRAD, 1999.

8. Andoh-Mensah E, Bonneau X, Ollivier J, Nuertey BN and SK Dery Evaluation of crop management options for replanting of coconut plantations devastated by lethal yellowing disease in Ghana. Cord, 2005; 21(2): 63-67.

9. Santos GA, Batugal PA, Othman A, Baudouin L and JP Laboisse Manual on standardized research techniques in coconut breeding. IPGRI-APO, Serdang, Malaysia. 1996.

10. Obreza TA Program fertilization for establishment of oranges trees. J. Prod. Agric. 1993; 6:546-552. 
11. Mead R and RW Willey The concept of land equivalent ratio and advantage in yield from intercropping. Exp. Agric. 1980; 16: 217-228.

12. Best $\mathbf{R}$ Production factors in the tropics. Neth. J. Agric. Sci. 1962; No. 10 (Special Ed): 347-360.

13. Liyanage M, Tejwani De SKG and PKR Nair Intercropping under coconuts in Sri Lanka. Agrofor. Syst. 1985; 2:215-228.

14. Magat SS Growing of intercrops in coconut lands to generate more food and agricultural products, jobs and enhancing farm incomes. Coconut intercropping salient notes/ considerations. Dept. of Agric., Phillippine Coconut Authority, 2004, pp. 7.

15. Ollivier J, Andoh-Mensah E, Arthur R and SK Dery Farmers' strategies and replanting performance in the context of coconut lethal yellowing disease along the coastal region in Ghana. Cord 2006; 22(1):66-75.

16. Lonsdale WM and AR Watkinson Light and self-thinning. New Phytologist, 1982; 90:431-435.

17. Canham CD, LePage PT and KD Coates A neighborhood analysis of canopy tree competition: Effect of shading versus crowding. Can. J. For. Res. 2004; 34:778-787.

18. Smart RE The influence of light on the composition and quality of grapes. Acta Hort. 1987; 206:37-47.

19. Norman MJK, Pearson CJ and PGE Searle Ecology of tropical food crops. $2^{\text {nd }}$ Ed. Cambridge, London, 1995. 